\title{
"Entre el palco y la butaca": el apaciguamiento británico y el regeneracionismo internacional de la España de Primo de Rivera ${ }^{1}$

\author{
"Entre el palco y la butaca": The British Appeasement and the \\ International Regenerationism of Primo de Rivera's Spain
}

\author{
José Luis Neila Hernández \\ Universidad Autónoma de Madrid \\ joseluis.neila@uam.es \\ ORCID: 0000-0001-7598-9878
}

Recibido: 23-11-2016

Aceptado: 15-3-2017

Cómo citar este artículo / Citation: NEILA HERNÁNDEZ, José Luis (2017). "Entre el palco y la butaca": el apaciguamiento británico y el regeneracionismo internacional de la España de Primo de Rivera. Pasado y Memoria. Revista de Historia Contemporánea, 16, pp. 47-67. https://doi.org/10.14198/PASADO2017.16.03

\section{Resumen}

La imagen de España en Gran Bretaña, y especialmente en medios diplomáticos, durante la Dictadura del general Primo de Rivera proyectaría todo un lienzo de estereotipos profundamente arraigados en la cultura inglesa y representaciones matizadas por la coyuntura histórica. Un juego de espejos donde tópicos como el retraso, la ineficacia y el orientalismo -luego codificados por el hispanismo- convivirían con planteamientos apaciguadores. El apaciguamiento mediatizaría la visión en torno a las dictaduras mediterráneas, como la Italia de Mussolini y la España de Primo de Rivera.

Palabras clave: Dictadura de Primo de Rivera, Historia de las Relaciones Internacionales, Imágenes, España, Siglo XX.

\footnotetext{
${ }^{1}$ Este trabajo se inserta en el marco del proyecto I+D+i Retos de la Sociedad del Ministerio de Economía y Competitividad titulado "Imágenes y percepciones. La inserción de España en el mundo actual" (HAR2013-43152-R). Investigadores principales: José Luis Neila Hernández y Pedro A. Martínez Lillo. Duración: 1/I/2014-31/XII/2016.
} 


\begin{abstract}
The image of Spain in the United Kingdom, and especially in diplomatic spheres, during the General Primo de Rivera's Dictatorship depicts a range of stereotypes rooted in English culture and other representations influenced by the historical context. It was a game of mirrors where topics like backwardness, inefficiency and orientalism -later encoded by Hispanism- coexisted with appeasing approaches. Appeasement would shape British attitudes toward Mediterranean dictatorships such as those of Italy under Mussolini or Spain under General Primo de Rivera.
\end{abstract}

Keywords: Primo Rivera's Dictatorship, World Politics, Images, Spain, $20^{\text {th }}$ Century.

El 13 de septiembre de 1923, escribía el embajador británico en Madrid sir Esme Howard, "the country was roused from the usual summer siesta" con la noticia de que el capitán general de Cataluña, el general Primo de Rivera había declarado la ley marcial ${ }^{2}$. Se suspendía la legalidad constitucional de 1876 y se iniciaría un periplo autoritario en clave regeneracionista, que en cierto modo había sorprendido a la diplomacia británica (Tusell; Queipo de Llano, 1986: 19). El propio embajador británico al valorar el cansancio de los españoles por la incapacidad de los Gobiernos del sistema de turno y no intuir esperanzas de mejora, estimaba que se mantendrían indiferentes y apáticos como consecuencia tanto de su desesperanza como del "oriental fatalism" que parecía arraigado en el carácter español ${ }^{3}$. El recurso a dichas expresiones por parte del representante británico ilustraría el poso en la cultura política británica de un caudal de imágenes y estereotipos que engarzarían con una determinada visión de España. Una imagen asociada con su atraso respecto a la modernidad y pincelada de tonalidades orientalizantes, que en última instancia remitían a su condición semiperiférica en el sistema internacional. ¿En qué medida estos registros textuales filtrarían la gravidez de los prejuicios y estereotipos en la cultura británica respecto a España? ¿Hasta qué punto responderían a las secuelas culturales de la leyenda negra y los mitos del romanticismo?, y delimitando el objetivo central de estas páginas ¿De qué modo este marco preinterpretativo determinaría la imagen construida en Gran Bretaña sobre la España del general Primo de Rivera y su política exterior? ¿Y en qué términos, si los hubo, este pliego de imágenes y actitudes hacia la dictadura española mostró alguna analogía con las pautas textuales del Foreign Office hacia la dictadura fascista en Italia y la práctica de la política de apaciguamiento de Londres?

\footnotetext{
${ }^{2}$ PUBLIC RECORD OFFICE (FOREIGN OFFICE) -en adelante FO- 371 10595. Annual Report for Spain, 1923.

${ }^{3}$ FO 371 9490. D. n. 1 Sir Esme Howard to the Marquess Curzon of Kedleston, Madrid, 26-IX-1923.
} 
El cosmos de imágenes, estereotipos y clichés que sobre los Estados y las naciones cristalizan en la literatura y las artes y, en definitiva, en la malla textual de la cultura o culturas de un país influirían de modo determinante en la relación entre conocimiento y poder. Unos prejuicios, fundamentales en la construcción del relato nacional y la extranjerización del otro, que serían sometidos a una severa roturación desde la teoría social y la historiografía, como así devendría desde el hispanismo anglosajón (Moradiellos, 1998: 189).

La articulación de una ciudadanía bajo el paraguas de una identidad común tiende a extranjerizar todo aquello que se entiende como diferente. En este sentido la política exterior sirve a un discurso y a una práctica que tiende a proyectar dicha extranjerización más allá de las fronteras nacionales y en el que la construcción del extranjero deriva, asimismo, de la constitución de lo doméstico (Campbell, 1998: 69-70).

En el proceso a tenor del cual se habrían ido sucediendo diversos diseños de modernidad, sobre cuyos fundamentos se habría articulado una epistemología de la dominación, Walter D. Mignolo, destacaría la naturaleza del primer diseño acaecido desde el siglo XVI, en el que España desempeñaría un destacado protagonismo, a partir del ímpetu del Orbis Universalis Christianus, y la condición semiperiférica en que quedaría retratada en el segundo diseño del sistema-mundo moderno/colonial. Un diseño acaecido al socaire del protagonismo de Inglaterra y de Francia desde finales del siglo XVIII. En el camino la noción de hegemonía de la "misión cristiana" sería reemplazada por la "misión civilizadora". El espacio, dominante en el imaginario de la etapa precedente de la expansión colonial, dejaría paso al tiempo. Éste, desde finales del siglo XVIII, reordenó la historia universal y se convirtió en esencia de la modernidad. El tiempo lineal de la historia universal se atrincheró, además, en la propia idea de la misión civilizadora: ser civilizado es ser moderno, y ser moderno significa estar en el presente. Así pues, la denegación de la coetaneidad se convirtió en una de las estrategias más poderosas para la colonialidad del poder en la subalternización de lenguas, conocimientos y culturas.

Desde este horizonte geocultural y discursivo, codificado desde las claves episemológicas del standard of Civilization, se modelarían en buena medida las imágenes y estereotipos sobre España y los españoles en la cultura inglesa en el marco de la posguerra mundial y la década de 1920.

Hasta que comenzó a codificarse el hispanismo británico a partir de la obra de Gerald Brenan la imagen de España y la explicación de su historia contemporánea se había basado en "interpretaciones apriorísticas sobre el carácter innato de los españoles y de la consideración de España como enigma histórico inaprensible y ajeno al resto de los países europeos" (Moradiellos, 1998: 189-190). 
Algunos juicios como los emitidos en tiempos de la guerra civil española por el agregado militar británico, el mayor Edmond Mahony, sentenciaba que el "español no es un hombre que se guie por la razón y tampoco valora la sabiduría si ésta aconseja algo que va en contra de lo que le dictan sus instintos". Es un "completo esclavo de sus pasiones" (Moradiellos, 1998: 186).

Tanto los sectores populares británicos como los círculos oficiales, afirma Enrique Moradiellos (1998: 186-188), "tendieron a descifrar e interpretar el complejo conflicto español de acuerdo con las ideas y concepciones abrigadas sobre España y el carácter de los españoles". Unas preconcepciones que emanaban de un dilatado pasado en sus relaciones bilaterales y cuyas predilectas manifestaciones se habían codificado en dos núcleos de estereotipos: la Leyenda de la España Negra y el Mito de la España Romántica. Los orígenes de la Leyenda Negra devendrían de las reticencias suscitadas en diversos países europeos ante la hegemonía alcanzada por la monarquía católica hispana durante casi todo el siglo XVI. El carácter de los españoles ilustraba un catálogo pincelado por tres de los atributos más reiterados por la literatura de la Leyenda Negra en el siglo XVI Cruelty, Bigotry y Vanity -crueldad, fanatismo y vanidosa arrogancia- y que remitirían a tres de los tipos humanos españoles más tópicos: el "conquistador de Indias cruel, el Inquisidor fanático y torturador, y el hidalgo altanero de insoportable suficiencia". Por su lado, el Mito Romántico que emergería desde comienzos del siglo XIX codificaría una visión de España y sus gentes en un contexto internacional bien diferente. La guerra de independencia suscitaría un desconocido entusiasmo hacia España en Gran Bretaña, que acabaría por concluir en una alianza política y militar contra el imperio francés. El nuevo tipo se superpondría y con el tiempo conviviría con el nuevo caudal de imágenes que emergerían en este nuevo contexto. Los viejos vicios se recodificarían en la pluma de los poetas románticos británicos como Lord Byron o sir Walter Scott y de los viajeros británicos como George Borrow o Richard Ford. Así la "crueldad hispana se convirtió en valentía indómita, el execrable fanatismo devino en pasión indomable, y la soberbia altanera se hizo orgullo patriótico e individualista".

La deriva de la Monarquía parlamentaria de Alfonso XIII, fuertemente erosionada por su incapacidad para hacer frente a los graves problemas del país -el problema marroquí, el desafío del Ejército al poder civil, los nacionalismos periféricos, los problemas estructurales del tejido socio-económico o la ineficacia del Estado, entre otros- no pasaban desapercibidos a una diplomacia tan bien informada como la británica. Este collage de inestabilidad orbitaría coyunturalmente sobre el poso de estereotipos e imágenes subyacentes a la cultura británica sobre España. La implantación de la Dictadura de Primo de 
Rivera a tenor del golpe de estado nos conduciría en el curso de estas páginas a indagar en la modulación de imágenes que fueron aflorando respecto a la percepción de España a lo largo de la dictadura y en el terreno de las relaciones bilaterales y en sus escenarios de contacto de la política internacional en el contexto de la política de apaciguamiento de Londres.

\section{La mirada británica hacia la España semiperiférica del general Primo de Rivera}

El golpe de estado, como advertía el embajador británico en Madrid sir Esme Howard, fue una sorpresa. Ciertamente habían circulado rumores y noticias pero nunca hasta ese momento, la fecha del 13 de septiembre de 1923, se había concretado. Nadie esperaba que tuviera lugar y menos aún que el Gobierno parlamentario se desmoronase como un castillo de naipes -house of cards-. En sus despachos ya había informado al Foreign Office del agotamiento de la opinión pública por la incapacidad del Gobierno de los "políticos" y como había ido calando un sentimiento general de disgusto hacia el modo en cómo en España se practicaba el Gobierno parlamentario y las prácticas corruptas continuadas en el sistema electoral ${ }^{4}$. El Ejército, asimismo, no gozaba de respaldo popular, ya que la opinión pública lo asociaba con la agitación de las juntas militares y estaba tan desacreditado como los "políticos". La preocupación por la crisis del parlamentarismo en España era desde hacía un tiempo, como bien ilustra Ángeles Lario (2015: 164), el tema "estrella" en los informes de los diplomáticos británicos acreditados en España.

Esta preocupación, en el contexto de agitación social y huelguística de España iniciado en 1917 en plena Guerra Mundial y a rebufo de la ola revolucionaria que recorrería toda Europa, había llevado al anterior embajador británico en Madrid Arthur Hardinge, en un informe fechado a comienzos de 1919, a insistir en la labor de los agitadores rusos y los anarquistas a sueldo alemán para fomentar los disturbios. España, pese a no estar sometida a las carestías vividas por los países implicados en la contienda, era un país abonado como consecuencia de la incompetencia y la corrupción de su gobierno ${ }^{5}$.

En el momento en que se consumó el golpe de estado en España, el secretario del Foreign Office Lord Curzon -político de talante conservador- mostraría una "actitud entre displicente con los regímenes dictatoriales" -aunque estos

\footnotetext{
${ }^{4}$ FO 371 9490. D. n. 1 Sir Esme Howard to the Marquess Curzon of Kedleston, Madrid, 26-IX-1923.

${ }^{5}$ Memorandum sobre la situación de España, Madrid, 23 de enero de 1919 (en Larios, 2015: 189).
} 
fueran impropios de países civilizados- y "deseosos de llevar a sus naciones a un papel de mayor relevancia en la política internacional". Tras el corto interludio del gabinete presidido por el líder del partido Laborista Ramsay MacDonald, el retorno de los conservadores llevaría al Foreign Office a Austen Chamberlain, protagonista esencial de la política de appeasement en el curso de la década. Su relación con las dictaduras mediterráneas, en particular con Italia había sido calificada de "complaciente con Mussolini". Había muchos conservadores, como el propio Winston Churchill, que no dudaban en "alabar a Mussolini como baluarte ante el comunismo", aunque estaban persuadidos de que el fascismo no era algo "que pudiera ser aclimatado en Gran Bretaña". La actitud del Foreign Office se codificó desde estos años en clave appeaser y es desde esta perspectiva desde donde hay que modular su percepción y su comportamiento hacia las dictaduras mediterráneas. En suma, "La postura británica con respecto a la España de Primo de Rivera" no fue, por tanto, "tan diferente de la mantenida con respecto a la Italia de Mussolini" (Tusell; Queipo de Llano, 1986: 16-18). En el curso de la década no se les percibió como una amenaza para el equilibrio del Mediterráneo y la paz en Europa.

La Dictadura de Primo de Rivera abriría paso en el Regeneracionismo político en un sendero al margen de la legalidad de la Constitución de 1876 y de contenido autoritario, pero al amparo de la Monarquía. El general Primo de Rivera se vería a sí mismo como el "cirujano de hierro" de la literatura costista. En este sentido se manifestaría el embajador británico, Sir Horace Rumbold que asumiría la representación diplomática en Madrid hasta el verano de 1929, al valorar la respuesta de Primo de Rivera a una carta elevada por la Unión Patriótica con motivo del tercer aniversario del golpe de estado. Al socaire de sus palabras el embajador británico deducía que el Gobierno no tenía ninguna intención de restituir el sistema parlamentario ante la eventual convocatoria de una Asamblea Nacional en la que estuvieran representados todas las clases e intereses del país. Los gestos de la Unión Patriótica y del Gobierno parecían discurrir en la línea de una política de regeneración ${ }^{6}$. Antes aún el propio embajador al diseccionar la naturaleza del Somatén en 1924 lo asociaba al ámbito de los "older boy scouts", con los que compartía a menudo objetivos como la estabilidad, la disciplina y la buena ciudadanía. A su juicio, pese a las opiniones que entablaban algún paralelismo entre el Fascismo en Italia y el Directorio en España, esta analogía no estaba justificada ${ }^{7}$.

${ }^{6}$ FO 371 11936. D. n. 411. Sir H. Rumbold to Sir A. Chamberlain. Madrid, 9-IX-1926.

${ }^{7}$ FO 371 10593. D. n. 447. Sir H. Rumbold to Mr. MacDonald. Madrid, 19-VIII-1924. 
El plebiscito que organizaría en septiembre de 1926 la Unión Patriótica, en un contexto de efervescencia nacionalista del Régimen primorriverista, a tenor de los éxitos en su política exterior y en el orden interno, lejos de ser el reflejo de la opinión pública proyectaba una gubernamentalidad discursiva propiciatoria para la prevalencia del sistema, toda vez que se había troquelado el camino desde el Directorio Militar al Directorio Civil desde diciembre de 1925. La dictadura asociada a la personalidad del general aparecía indisolublemente vinculada, como bien argumentaba el embajador británico, a la figura de Alfonso XIII. Al amparo de su patriotismo tanto uno como otro eran cómplices del golpe de estado y la violación de la Constitución de $1876^{8}$.

El acceso a la Secretaría del Foreign Office de sir Austen Chamberlain allanaría sustancialmente las relaciones entre Londres y Madrid, no sólo por el propio talante de la política de apaciguamiento como elemento estructural, sino también por la empatía personal que mantenía con Alfonso XIII.

En 1926 la figura del general Primo de Rivera era caracterizada por sir Horace Rumbold como un hombre enérgico, de gran valor físico y moral. Lo definía como un jugador, listo para asumir riesgos políticos y firmemente confiado en su propia estrella. La mayoría de los españoles, a excepción de los viejos políticos del turno, parecían satisfechos con la situación general y parecían conformes con la continuidad del liderazgo de Primo de Rivera, al margen del cual se vislumbraba ninguna alternativa para reemplazarle ${ }^{9}$.

No percibía motivos sir Horace Rumbold, a la altura de septiembre de 1926, para que no permaneciese en el poder por varios años más el general Primo de Rivera, pues gozaba de gran autoridad en el seno del Ejército y el apoyo de la Iglesia, así como entre buena parte de la población, especialmente entre los sectores menos instruidos y más insensibles hacia la forma de Gobierno ${ }^{10}$. El Ejército, uno de los principales pilares de la Dictadura, era un factor fundamental en la vida política española. Así lo ponía de relieve en el informe anual del año 1923 Sir Esme Howard remitiendo a la incidencia de las juntas militares en el devenir reciente de la historia de España ${ }^{11}$ y más adelante Sir Horace Rumbold al valorar la posición del Ejército en $1924^{12}$.

La Iglesia había acogido de buen grado a la Dictadura. Con motivo del viaje, ya programado antes del golpe de Estado, de Alfonso XIII a Roma, acompañado del general Primo de Rivera. En noviembre de 1923 tendría lugar la visi-

\footnotetext{
${ }^{8}$ FO 371 11936. D. n. 426. Sir H. Rumbold to Sir A. Chamberlain. Madrid, 27-IX-1926

${ }^{9}$ FO 371 11945. D. n. 601. Sir H. Rumbold to Sir A. Chamberlain. Madrid, 20-XII-1926.

${ }^{10}$ FO 371 11936. D. n. 426. Sir H. Rumbold to Sir A. Chamberlain. Madrid, 27-IX-1926.

${ }^{11}$ FO 371 10595. Annual Report for Spain, 1923.

${ }^{12}$ FO 371 10593. D. n. 447. Sir H. Rumbold to Mr. MacDonald. Madrid, 19-VIII-1924.
} 
ta a Víctor Manuel III y al Papa Pío XI. El viaje como reconocían las fuentes diplomáticas británicas estuvo cargado de un evidente significado político muy por encima de sus resultados prácticos. En la retórica de proximidad a la Italia de Mussolini con la que se manifestó Alfonso XIII, quién presentó al general Primo de Rivera como "mi Mussolini" ${ }^{13}$, tendría lugar un episodio paralelo con motivo de la visita a la Santa Sede. El 19 de noviembre el discurso pronunciado por el monarca español ante Pío XI se embarcaría en referencias históricas alusivas a la lucha secular contra el Islam, inoportunas en opinión de sir Esme Howard a tenor de la situación de la empresa militar de España en el Norte de África para "implantar la justicia y la civilización", y la lucha contra los protestantes en los Países Bajos en el siglo XVI. Unas palabras que concitarían las críticas en los círculos liberales españoles -entre éstos el conde de Romanones y Miguel de Unamuno o el silencio de periódicos como El Liberal y la crítica abierta desde las páginas de El Sol-, frente a la cálida acogida dispensada desde la prensa clerical y tradicionalista ${ }^{14}$. El sentido de aquella intervención ante la Santa Sede, en opinión del embajador británico en Madrid, tenía por finalidad diluir las suspicacias de los sectores ultra católicos españoles que consideraban al Estado fascista italiano como enemigo de la Santa Sede ${ }^{15}$.

Las críticas veladas, en unas ocasiones, y explícitas, en otras, a la censura ejercida en España sobre la prensa desde los medios diplomáticos y gubernamentales británicos se sucederían en el curso de la década. Así se pondría de manifiesto con motivo de las protestas de Merry del Val hacia las opiniones críticas vertidas contra España por motivos de diversa índole como la política económica nacionalista y la creación de monopolios en el tramo final de la década o protestas puntuales hacia hechos controvertidos como la deportación de Miguel de Unamuno por sus declaraciones contra la Dictadura y la Monarquía (Pereira, 1979 y 1986).

En el seguimiento realizado por la diplomacia británica del devenir de la Dictadura no pasaría obviamente desapercibido la deriva del régimen hacia una suerte de mímesis del fascismo italiano cuando éste se embarcó hacia la búsqueda de una fórmula constitucional una vez que se convocó la Asamblea Nacional en septiembre de 1927. Un "propósito imitador" que fue "fallido,

${ }^{13}$ FO 371 9493.D. n. 1032. Sir R. Graham to Marquees Curzon of Kedleston. Rome, 1-XII-1923.

${ }^{14}$ FO 371 9493. D. n. 669. Sir E. Howard to Marquees Curzon of Kedleston. Madrid, 24-XI-1923.

${ }^{15}$ FO 371 9493. D. n. 698. Sir E. Howard to Marquees Curzon of Kedleston. Madrid, 7-XII- 1923. 
titubeante e impreciso" Tusell; Queipo de Llano, 1986: 82). En febrero de 1929 desde la Embajada británica en Madrid, Patrick Ramsay, valoraba las intenciones reformistas de Primo de Rivera en la articulación de un marco normativo corporativista en el mismo sentido de las recientes medidas adoptadas en Italia ${ }^{16}$. En este contexto se fueron erosionando los apoyos sociológicos de la Dictadura en el seno del propio Ejército, a tenor del pulso desde el cuerpo de Artillería, los círculos estudiantiles, la oposición de los círculos políticos tradicionales y al propio alejamiento del Rey. La Constitución proyectada desde la Asamblea Nacional concitaría, como bien advierte el nuevo embajador británico en Madrid Sir George Grahame, el rechazo de los opositores al régimen, quienes deseaban el retorno a las instituciones parlamentarias tal como imperaba en la mayor parte de los "países progresistas del mundo"17. En un mismo frente de rechazo a la reforma constitucional se pronunciarían el Partido Socialista Obrero Español y el sindicato Unión General de Trabajadores denunciando que mientras otros Estados tendían a democratizar sus constituciones, el gobierno español se proponía adoptar una estructura de despotismo oriental -Eastern Absolutism- ${ }^{18}$.

El retraso de España respecto a la modernidad era, si bien es cierto que con matices, un terreno de común roturación en la cultura política británica. En el seno del Foreign Office cohabitarían actitudes y percepciones más sensibles hacia España, como la manifestada por Sir Esme Howard o el propio sir Austen Chamberlain, con otras más severas como las de ciertos altos funcionarios del Foreign Office como Villiers, cuya actividad estaría estrechamente relacionada con España. En alguna ocasión había calificado al Gobierno español como "uno, si no el más, ineficiente y corrupto de Europa", además de negar cualquier peso internacional a España (Tusell; Queipo de Llano, 1986: 35).

En el contexto de la explosión de orgullo patriótico de 1926 el embajador británico Sir Horace Rumbold indagaba en torno a la dolida consideración que España percibía del trato de las grandes potencias europeas. Desde la mirada de sus vecinos España aparecía como un país ineficiente y desacreditado, así como incapaz de preservar la paz a través del progreso y la civilización. Los españoles sentían con amargura la incomprensión de las otras potencias para apreciar las dificultades que entrañaba su lucha en el Rif contra Abd-el-krim ${ }^{19}$.

Los éxitos que fue atesorando la Dictadura a lo largo del año 1926 fueron remodelando la autoimagen de España y su lugar en el mundo. Si en 1924 Sir

\footnotetext{
${ }^{16}$ FO 371 14164. D. n. 102. Mr. Ramsay to Sir A. Chamberlain. Madrid, 26-II-1929.

${ }^{17}$ FO 371 14164. D. n. 277. Sir G. Grahame to Mr. A. Henderson. Madrid, 18-VI-1929.

${ }^{18}$ FO 371 14164. D. n. 368. Sir G. Grahame to Mr. A. Henderson. Madrid, 26-VIII-1929.

${ }^{19}$ FO 371 11939. D. n. 41. Sir H. Rumbold to Sir A. Chamberlain. Madrid, 4-II-1926.
} 
Horace Rumbold constataba que los españoles y su gobierno tenían la percepción de que en el extranjero se les consideraba como una nación "retrasada y desacreditada, incapaz de solucionar sus problemas en Marruecos", en 1926 había aflorado de modo efervescente un sentimiento y un orgullo nacionalista que se escenificaría de inmediato en el activo del prestigio internacional y el tono de su política exterior (Tusell; Queipo de Llano, 1986: 42).

En el informe anual del año 1927 el embajador británico sir Horace Rumbold dedicaba una atención explícita al progreso de España en los últimos veinte años. A su juicio el reinado de Alfonso XIII había sido el más próspero para España en relación a sus predecesores, exceptuando dos cuestiones que habían sido destacadas desde las páginas del diario El Sol: el tema de la Constitución y la ilegalidad del Gobierno de Primo de Rivera. El progreso material experimentado por España en estas dos décadas había sido lo más visible, aunque era evidente el deseo de situar al país en un nivel cultural equiparable al de otros países europeos. Desde una aproximación empírica, mientras que el desarrollo del ferrocarril ha sido lento en cambio la mejora en la red de carreteras en España ha sido muy notable. Las principales ciudades han sido embellecidas y cuentan con hoteles de primera clase, del mismo modo que en ciudades más modestas es posible encontrar alojamientos más confortables. Una dinámica de cambio en la que polarizaba el papel del monarca como factor de estímulo que había encontrado un especial acomodo en el régimen del general Primo de Rivera ${ }^{20}$.

Esa cartografía del progreso material de España había sido el espacio roturado también en el curso de la iniciativa de The Times para publicar en 1926 un suplemento sobre España ${ }^{21}$. Un número dedicado especialmente a viajeros y hombres de negocios británicos, pero que pincelaría un fresco vivo de las imágenes y estereotipos reinantes sobre España y los españoles en la cultura británica indisociable de su marco coyuntural. Resulta de extraordinario interés el borrador realizado por Sir Horace Rumbold en febrero de aquel año y que proponía a su superior, Villiers, para enviarlo a The Times. En su opinión España era uno de los países más interesantes de Europa en razón de su historia, su diversidad de climas, razas, monumentos y características geográficas. Además de insistir en su reciente desarrollo material de cara a los visitantes aludía a los intereses económicos, la fuerte demanda de productos españoles en Gran Bretaña y la alta estima de los productos británicos pese a los altos aranceles y la

${ }^{20}$ FO 371 13439. Annual Report for Spain, 1927.

${ }^{21}$ El suplemento especial, que recibiría una subvención de 25.000 pesetas, se publicaría en The Times el 10 de agosto de 1926 con motivo de la visita del Rey Alfonso XIII. Un tema analizado por María Rosa Cal (1988) en el marco general de la política del dictador hacia la prensa. 
política de nacionalismo económico en España. Pero, sin duda, el pasaje más revelador del texto del embajador pincelaba los espacios comunes entre españoles y británicos al socaire de la historia, en un tono bien lejano de la leyenda negra e indagando en otros tópicos que navegan entre el romanticismo y la centralidad de ambas naciones en la historia moderna de Europa:

"The British and Spanish peoples have many points in common. Both have sent out explorers -Spain leading the way. Boh countries founded colonial Empires. The recent trans-Atlantic flight by Spanish aviators has once again furnished proof of Spanish courage, endurance and tenacity -qualities which specially appeal to the British race. Both races are imbued with a respect for tradition. Independence is a characteristic of the individual in both countries. The monarchy is rooted in the affections of the two peoples. English and Spanish are the two world-languages" 22 .

Un fresco que se iría impregnando de las inquietudes suscitadas por el propio decurso de la Dictadura, la inestabilidad interna, la deriva mimética hacia el fascismo, los contenciosos generados por la creación de monopolios como el de petróleos y cuyos matices se trenzarían en el espacio de la política exterior, como lienzos de externalización de la otredad y como escenarios de contacto de sus agendas internacionales. Precisamente estas tensiones suscitadas en las relaciones comerciales bilaterales, apuntadas por el nuevo embajador británico -Sir George Grahame-, en septiembre de 1929 estaban en el mar de fondo de noticias críticas hacia los recientes pasos políticos emprendidos desde el Directorio en un sentido corporativista y que habían dado lugar a alguna gestión diplomática cerca del Gabinete británico para que influyese sobre la prensa y que despertó ciertas críticas hacia la censura de prensa ejercida por el Gobierno español ${ }^{23}$. Las noticias publicadas en la prensa francesa y británica -the Economist, Daily Telegraph y Morning Post- suscitarían un manifiesto de españoles residentes en Londres ante el perjudicial efecto que podrían tener en el desarrollo de la Exposición Internacional de Barcelona y la Exposición Iberoamericana de Sevilla que se inaugurarían en el mes de mayo ${ }^{24}$.

\section{Inconformismo y prestigio internacional de España en la diplomacia del apaciguamiento}

Los años que transcurren entre 1923 y 1930/1931 fluyeron desde el golpe de timón interno de la Monarquía que se sumergió en el autoritarismo, cuyas

${ }^{22}$ FO 371 11940. Letter from Sir H. Rumbold to Mr.Villiers. Madrid, 8-II-1926.

${ }^{23}$ FO 371 14164. Carta confidencia de Merry del Val a sir A. Chamberlain, Londres, 19-III-1929 e informe de Villiers de 22-III-1929.

${ }^{24}$ FO 371 14164. D. n. 154. Sir G. Grahame to Sir A. Chamberlain. Madrid, 22-III-1929. 
directrices de política exterior se perfilarían, a menudo de forma incoherente e improvisada, en la inercia de los objetivos revisionistas y activos ${ }^{25}$.

Las pulsaciones de esa diplomacia asertiva que se enfatizarían durante la dictadura de Primo de Rivera se escenificarían en su política mediterránea y en el foro de la Sociedad de Naciones, sobre las que polarizamos nuestro interés para analizar las percepciones e imágenes modeladas desde la diplomacia y la cultura política británica, en el teatro de la política de apaciguamiento. El discurso que emanaría desde la Dictadura de Primo de Rivera respecto a los objetivos de la política exterior, cristalizados en estas páginas en la textura de la política de prestigio internacional, las ambiciones formales en la Sociedad de Naciones en aras al reconocimiento de sus estatus internacional en el seno del Consejo de la misma y sus conexiones con el eje gravitatorio de la política exterior, el Mediterráneo y Marruecos, serían objeto de una privilegiada atención desde los medios diplomáticos británicos. Escenarios centrales de la agenda internacional de España y situaciones que pincelarían un fresco vivo y simbólico de la percepción y la imagen de la posición internacional de España.

En la coyuntura de crisis interna e internacional, derivada fundamentalmente en este último caso por los estragos de la política marroquí, en la que tuvo lugar la imposición de la Dictadura de Primo de Rivera el nuevo régimen se vería abocado a hacer frente a las incertidumbres derivadas de su delicada posición internacional. La erosionada imagen internacional de España como consecuencia del descalabro militar en Marruecos en 1921 y la frágil posición en que se encontró para negociar el futuro de Tánger o sus aspiraciones a ocupar un puesto permanente en el Consejo de la Sociedad de Naciones se traducirían en un orgullo nacional herido y la búsqueda de un prestigio internacional que sería aguda y explícitamente percibido desde medios diplomáticos británicos ${ }^{26}$.

El encauzamiento de la cuestión marroquí entre el año 1924 y 1926 ilustraría un giro en el estado de ánimo de los responsables del nuevo régimen. El embajador británico en Madrid, sir Horace Rumbold así lo constataba a tenor de sus contactos con Primo de Rivera desde comienzos de 1926. Si dos años antes informaba de que los españoles y su gobierno percibían que en el extranjero se les percibía como una nación atrasada y desacreditada, incapaz de resolver sus problemas en Marruecos, en 1926 los éxitos internacionales de la Dictadura se manifestarían en un revitalizado sentimiento nacional y una resti-

${ }^{25}$ No es el propósito de estas páginas hacer un estudio de la política exterior de la Dictadura ni presentar un detallado estado de la cuestión, aspectos que remitimos a la consulta de trabajos anteriores (Neila, 2011; Pereira, Neila, 2007).

${ }^{26}$ FO 371 10595. Annual Report for Spain, 1923. 
tución del prestigio internacional (Tusell; Queipo de Llano, 1986: 42). Un estado de ánimo que contribuiría a elevar el tono asertivo y reivindicativo de la política exterior española. Una España internacional imaginada como gran potencia envuelta en una retórica muy distante de su capacidad real para que a si fuera reconocida. En el mes de mayo de aquel mismo año el embajador británico interpretaba la rígida actitud de España al sentirse "mortificada" por la falta de reconocimiento a su importancia.

En reiteradas ocasiones a lo largo de aquel año el embajador británico, sir Horace Rumbold, se referiría a la inercia reivindicativa de España. "The Spaniards -escribía el diplomático británico- felt the lost of prestige which this disaster has inflicted on the Spanish Army". En este contexto el éxito de la colaboración hispano-francesa en Marruecos y el desembarco de Alhucemas en octubre de 1925 y gestas de alto contenido simbólico como el viaje interoceánico del Plus Ultra alimentarían un discurso y un sentimiento de satisfacción y orgullo nacional ${ }^{27}$. El vuelo interoceánico del Plus Ultra -cuya tripulación estaba conformada por el comandante Ramón Franco, el capitán Julio Ruíz de Alda, el teniente de navío Juan Manuel Durán y el mecánico Pablo Rada- partió de Palos de la Frontera en Huelva el 22 de enero de 1926 y arribó a Buenos Aires el 10 de febrero. Un trayecto preñado de la simbología del descubrimiento que pretendía mostrar a las otras naciones que los "Spaniards were still capable of hold Enterprise and initiative" y gestualizar la relevancia que Hispanoamérica tenía para la proyección de España en el mundo e ilustrar la revitalización del nacionalismo español. La retórica que afloraría desde diferentes actores remitiría a lugares comunes del discurso respecto al imaginario y los activos de la posición internacional de España como la hidalguía como valor inherente de la raza española o el énfasis al resurgimiento nacional y la alusión al pasado glorioso a tenor de la conexión con sus antiguas colonias americanas a las que aludiría el Rey, en presencia del ministro de Marina, con motivo de la recepción en Huelva a los "héroes" del Plus Ultra ${ }^{28}$. Poco después y en un mismo registro discursivo, el 5 de abril de aquel mismo año partiría desde el Aeródromo de Cuatrovientos la "Escuadrilla Elcano" con destino a Manila en el archipiélago de las Filipinas, donde llegarían treinta y nueve días después.

En un discurso pronunciado por Primo de Rivera en Albacete en septiembre de 1926 recapitulaba sobre las promesas cumplidas tras la declaración realizada con motivo del golpe de estado y hacía balance del orden interno y

${ }^{27}$ FO 371 11939. D. n. 41 Sir H. Rumbold to Sir A. Chamberlain. Madrid, 4-II-1926.

${ }^{28}$ FO 371 1193. D. n. 143. Sir H. Rumbold to Sir A. Chamberlain. Madrid, 8-IV-1926. 
de la reconducción del capítulo de la guerra de Marruecos, ya en su fase de liquidación definitiva. No dudaba el embajador británico, sir Horace Rumbold, en afirmar que el general Primo de Rivera había logrado elevar el prestigio de España en el exterior ${ }^{29}$.

El asunto que mejor capitalizaría las ambiciones de la política de prestigio primorriverista sería la aspiración a lograr un puesto permanente en el Consejo de la Sociedad de Naciones. Una batalla diplomática en la que se implicaron plenamente tanto Alfonso XIII como el general Primo de Rivera. En este sentido se movilizaría la diplomacia del rey, cerca de Jorge V, en un tono quizás más inquisitivo en opinión de Javier Tusell y Genoveva García Queipo de Llano (1986: 55), al entender que España no podía tener una presencia "precaria e intermitente" en el Consejo de la Sociedad de Naciones. En esa línea asertiva se escenificarían las intervenciones del general Primo de Rivera para quién la opinión pública española estaba "sedienta" por ver que "nuestro país figure entre las Naciones de primer orden", como reconocimiento no tanto por su poder militar o naval como por "su influencia en la civilización moderna". En unas declaraciones efectuadas por Primo de Rivera al diario La Nación el 18 de agosto de 1926, afirmaba que:

"Respecto a la Sociedad de Naciones, el sentir y pensar de España es acorde y lógico con el que tiene respecto a Tánger. Cree que, a pesar de su abolengo, de su estirpe, de su actuación mundial en el pasado, podría vivir retirada y alejada de las pugnas y ostentaciones internacionales (...), pero llamada a intervenir en ellas, su decoro, no su orgullo, le impone presentarse en lugar de preferencia. Al teatro del mundo no puede asistir España, la gloriosa España, madre de cien pueblos, a anfiteatro, ni siquiera a butaca: debe ir a palco" (en Pereira; Cervantes, 1992: 215).

Para la diplomacia monárquica Ginebra fue básicamente un instrumento, útil en la medida en que pudiera servir a los intereses nacionales, y Europa quedaba relegada a un segundo plano en función de los asuntos extra-europeos mediterráneos -Marruecos y Tánger fundamentalmente-.

La dictadura retomaría el testigo de la diplomacia alfonsina para alcanzar un puesto permanente y situar a España en el club de las grandes potencias o disfrazarla de las "exterioridades de gran potencia" -en palabras de Fernando Albi (1931: 199). La dictadura emprendería su "batalla diplomática" a partir de 1926-.

${ }^{29}$ FO 371 11936. D. n. 426. Sir H. Rumbold to Sir A. Chamberlain. Madrid, September $27,1926$. 
La diplomacia española hizo explícitas sus aspiraciones en el Consejo el 26 de febrero de 1926 y de modo taxativo pues se le manifestaría al propio secretario general de la Sociedad de Naciones, Sir Eric Drummond que de no ser así España estaría dispuesta a abandonar la organización internacional.

La aspiración planteada como una cuestión de honor fue reduciendo paulatinamente la capacidad de maniobra de la diplomacia española a medida que fue creciendo su frustración. Así al improbable logro del puesto permanente sucedió una opción compensatoria, la mejora de la posición española en Tánger como baza de negociación en la "última ofensiva diplomática" de España a partir del mes de julio de 1926. La diplomacia británica del apaciguamiento había tratado de mediar y flexibilizar la actitud española hacia sus aspiraciones en el Consejo. Para entonces tanto Sir Horace Rumbold en Madrid como Sir Austen Chamberlain en Ginebra habían advertido del daño que la retirada de la Sociedad de Naciones tendría en el prestigio internacional de España.

El comportamiento de la diplomacia española no obedeció, por tanto, únicamente al dictado de una política de prestigio, sino también a sus inquietudes en el Mediterráneo. Uno y otro fracasaron en 1926. España, aislada diplomáticamente, se vería abocada a abandonar la Sociedad de Naciones a primeros de septiembre mientras la cuestión de Tánger -sobre la que volveremos en breve- no había mostrado en principio progreso alguno. La diplomacia primorriverista se había enclaustrado, como advertía Sir Horace Rumbold en su "cerrado orgullo nacional". Otros funcionarios menos sensibles a las aspiraciones españolas, como Villiers, eran abiertamente críticos y hostiles, valorando que la retirada de España de Ginebra desde el punto de vista práctico no tendría grandes efectos.

En la gestión política de la aspiración española en el Consejo ya hemos hecho mención a la implicación de la diplomacia del Rey, pero las fuentes diplomáticas británicas apuntaban sobre todo al personalismo que imprimiría Primo de Rivera en la política exterior, el cual iría in crescendo cuando tras la dimisión de José Yanguas.

El modo de hacer del general Primo de Rivera se entretejía desde su aproximación "amateur" y desde su realismo en materia de política exterior. Sólo así podía explicarse, en opinión, de Sir Horace Rumbold, la interferencia de las demandas sobre Tánger con las aspiraciones españolas a ocupar un puesto permanente en el Consejo ${ }^{30}$. En el encuentro que mantuvieron en Palma de Mallorca Sir Austen Chamberlain y el general Primo de Rivera el 30 de sep-

${ }^{30}$ FO 371 12715. D. n. 605. Sir H. Rumbold to Sir A. Chamberlain. Madrid, 21-XI-1927. 
tiembre de 1927, en el transcurso de la cual Tánger y el eventual retorno de España a la Sociedad de Naciones capitalizaron buena parte de la agenda, el secretario del Foreign Office tenía la impresión a tenor de las palabras y la actitud de Primo de Rivera de la asunción del error cometido por España al abandonar la Sociedad de Naciones. Sus aspiraciones internacionales y su prestigio, parcialmente diezmado tras su abandono, pasaban por el retorno a la Sociedad de Naciones. La posición de España, fuera de Ginebra, era una anomalía ${ }^{31}$. No erraba Sir Austen Chamberlain al entender y actuar en consecuencia de que la solución del problema de Tánger despejaría el camino para el retorno de España a la Sociedad de Naciones y el Consejo. La reinserción de España en Ginebra cristalizaría en septiembre de 1928, ocupando un puesto semipermanente.

Con el retorno a la Sociedad de Naciones la Dictadura normalizó su política exterior y seguiría promoviendo, en un contexto interno más crítico, los gestos de una política de prestigio imbuida de la retórica nacionalista tradicionalmente proyectada por la Dictadura pero con escaso contenido práctico. Este sería el destino de una última batalla diplomática, también frustrada, por aparecer entre los firmantes del Pacto Briand-Kellogg el 28 de agosto de 1928, y al que uniría su firma en febrero de 1929. Y, asimismo, uno de los últimos gestos de la política de prestigio de la Dictadura se consumaría con la celebración en Madrid de la reunión del Consejo de la Sociedad de Naciones en junio de 1929.

En el plano de la seguridad colectiva, la instrumentalización de la política de la Monarquía en Ginebra al socaire de sus intereses mediterráneos se plasmaría con nitidez en su actitud hacia la seguridad colectiva.

España necesitaba una posición de equilibrio en sus relaciones con Londres, París y Roma. Luego, la idea estratégica española imperante hasta el estallido de la guerra civil en 1936 consistió, según afirma J. Salgado Alba (1989: 139), en tratar de ejercer el papel de "potencia equilibradora en esa zona del Mediterráneo", en el marco de la rivalidad franco-italiana. El agregado naval británico coincidía en la valoración de tales parámetros en 1927:

(...) "Spain has a unique geographical situation in Europe for the exercice of sea power many important lines of commercial communications passing close their coasts, and of that situation she is well aware. So that the possession of an efficient and even small fleet would place her in such a position that she could not be ignored or brushed aside by even the greatest Powers when international question which might lead to war were on the "tapis". In other words, her weight in the scale would always have to be considered" 32 .

${ }^{31}$ FO 371 13439. Annual Report for Spain, 1927.

${ }^{32}$ FO 371 13439. Annual Report for Spain, 1927. 
Por último, el Mediterráneo y, en particular, Marruecos continuaría siendo el eje central de la agenda de la política exterior española desde principios de siglo y continuaría siéndolo durante la década de 1920. El capítulo de la batalla diplomática en torno al puesto permanente en el Consejo ilustra bien las pulsaciones y las pulsiones mediterráneas de la política española. La centralidad del Mediterráneo en la política exterior española, la auténtica ventana hacia la política europea, era una vertiente bien conocida para la diplomacia británica. Para el embajador británico en Madrid, Sir Horace Rumbold, en un despacho enviado al Foreign Office el 21 de noviembre de 1927 no cabía lugar a equívoco:

"In my view, the foreign relations of Spain during the last three o four years, i.e., since the advent to power of the Present Government have been considered and determined, above all, in relations to Spanish aspirations in the international zone of Morocco and to the difficulties in their own zone"33.

Sin embargo, el cambio de Gobierno en España, la precaria situación de la zona española tras el Desastre con el consecuente repliegue militar y las tesis bien conocidas por la diplomacia británica del general Primo de Rivera sobre la presencia de España en Marruecos y la cuestión de Gibraltar ${ }^{34}$, en un contexto mediatizado por la aproximación a Italia suscitarían lógicas incertidumbres en los medios diplomáticos y políticos británicos.

A raíz del nuevo desastre colonial resurgió en España el "sentimiento de derrotismo", de la concepción de España como una nación moribunda. Sin embargo, la tentación de inhibición internacional fue, en esta ocasión, un fenómeno pasajero. La humillación de Annual provocó, a su vez, un estallido de rencor acumulado hacia las potencias directoras del equilibrio mediterráneo -Francia y, en menor medida, Gran Bretaña-. En el año 1923 el último Gobierno de la Monarquía constitucional, el Gobierno de García Prieto, iniciaría una "fase de rebeldía" -en palabras de Susana Sueiro (2000: 141)- que luego tendría su continuidad y paroxismo durante la dictadura de Primo de Rivera.

${ }^{33}$ FO 371 12715. D. n. 605. Sir H. Rumbold to Sir A. Chamberlain. Madrid, 21-XI-1927.

${ }^{34}$ El 25 de marzo de 1917 lo hizo explícito en un discurso ante la Real Sociedad Hispanoamericana sobre "La recuperación de Gibraltar" en el que proponía que se realizara el canje por Ceuta y abandonar la idea de recuperar Tánger. En Gran Bretaña se suscitó una corriente de opinión favorable a estudiar la cuestión, creándose una Comisión para estudiar la posibilidad del cambio de Gibraltar por Ceuta, lo que cobraría curso a partir de abril de 1917 bajo la presidencia de Lord Curzon. La cuestión se daría por zanjada en una reunión de la comisión Gibraltar-Ceuta en la Secretaría del Foreign Office el 10 de enero de 1919 desestimando el trueque e invocando el importante valor simbólico de Gibraltar (Pereira, 1986: 1376 y ss.). 
Una rebeldía que tendría su primera escenificación en las negociaciones sobre el futuro estatuto de Tánger. En 1923 se establecería un Estatuto que sancionaba la internacionalización, por un lado, y la supremacía francesa en la ciudad, por otro. España lo firmó ad referendum, con reservas expresas.

En el contexto de aquellas conversaciones sobre Tánger se suscitó por parte de España la posible ampliación de la zona fronteriza de Ceuta y Melilla con vistas a un posible trueque con Gibraltar. En el mes de mayo realizaría una propuesta en este sentido al embajador Sir Horace Rumbold. La diplomacia británica se negaría a reabrir la cuestión y en este sentido instruiría a su embajador tanto en aquel momento como en el mes de mayo de 1925: "no British Government at the present moment could take his suggestion into consideration as a matter of practical politics" 35 .

Si Alemania se había convertido en el factor disruptivo en el acomodo de España en el statu quo franco-británico en el Mediterráneo Occidental antes de la Guerra del Catorce y en la escenificación de una política más asertiva, Italia desempeñaría ese role en el curso de la década de 1920, especialmente durante la dictadura de Primo de Rivera.

Para los medios diplomáticos británicos en Madrid el viraje más significativo de la política exterior española en el curso del año 1923 había sido la aproximación hispano-italiana, aunque ya se habían apreciado inequívocos pasos en este sentido desde 1920. Pese a las especulaciones suscitadas en la prensa respecto a los resultados políticos del viaje de Alfonso XIII y el general Primo de Rivera a Roma, el general Primo de Rivera le informó a Sir Esme Howard que había instruido al embajador español en Londres para que informase al Gabinete británico de que había hablado con Mussolini de la cooperación bilateral, especialmente en los asuntos mediterráneos, pero sin perturbar los intereses británicos ni alterar el statu quo mediterráneo y la preservación de la paz ${ }^{36}$.

Desde un principio la Dictadura puso de manifiesto la centralidad de Gran Bretaña en la política exterior española, especialmente en el Mediterráneo y en los asuntos europeos. A la estela de Locarno el embajador británico en España Sir Horace Rumbold comentaba que desde la percepción de los españoles Gran Bretaña desempeñaba un papel predominante en el mundo y de liderazgo en Europa. Su concurso, asimismo, resultaba capital para cualquier cuestión relacionada con el futuro de la zona española de Marruecos ${ }^{37}$.

${ }^{35}$ FO 371 11942. Annual Report for Spain, 1925.

${ }^{36}$ FO 371 10595. Annual Report for Spain, 1923.

${ }^{37}$ FO 371 11942. Annual Report for Spain, 1925. 
Al establecerse el Directorio Militar, Primo de Rivera se vio sometido a la presión internacional e interna en la búsqueda de soluciones al problema. En un principio compartió y asumió el repliegue limitando la zona ocupada en el Protectorado para ahorrar vidas y reducir gastos (Sueiro, 1992).

Entre tanto, el Directorio contemplaría diversas alternativas -oscilantes entre la idea que comenzaba a cobrar cuerpo de una intervención militar a mayor escala, las negociaciones con Abd el-Krim e incluso negociar con Francia y Gran Bretaña la alteración del statu quo marroquí, horizonte en el que se contemplaría desde el abandono de la zona hasta la permuta de territorios como el de Ceuta por Gibraltar-. Pero Francia y Gran Bretaña hicieron caso omiso de aquellas propuestas.

La agresiva actividad de Abd el-Krim en la zona francesa, en plena euforia tras su éxito ante España, modificaría radicalmente la situación, de modo que impulsó la colaboración político-militar franco-española. Las acciones militares españolas, en coordinación con las francesas, cristalizarían en el mayor éxito militar y político-diplomático de la dictadura, el desembarco de Alhucemas en septiembre de 1925.

Muchos españoles, ávidos de reivindicar el honor de su ejército, comparaban el éxito de aquella operación militar en contraste con la forzada retirada de la fuerza expedicionaria del imperio británico en los Dardanelos durante la Guerra del Catorce ${ }^{38}$. El desembarco español en Alhucemas causaría en el Foreign Office una "mezcla de sorpresa, complejo de superioridad y alegría". En el informe elaborado sobre la operación militar se matizaba que "a pesar del aparente desorden y falta de método (en el desembarco) que es tan sorprendente para nosotros, los españoles lo lograron" (Tusell; Queipo de Llano, 1986: 40).

En el discurso pronunciado por Primo de Rivera en Albacete en septiembre de 1926, el dictador enfatizaba el reencauzamiento de la cuestión marroquí mediante una "acción vigorosa" en colaboración con Francia, a tenor del desembarco en la bahía de Alhucemas, y el epílogo a la República del Rif y de Abd-el-krim. Un pasaje que había elevado el prestigio internacional de España y restituido la autoestima del Ejército ${ }^{39}$.

En el curso del año 1926 el tono más asertivo de la diplomacia de la España de la Dictadura acabaría por dejar al descubierto la centralidad de la política mediterránea y el componente utilitarista de la política en la Sociedad de Naciones. A lo largo de aquel año se iría abriendo paso la idea de la apertura de conversaciones sobre Tánger. El secretario del Foreign Office, Austen Cham-

${ }^{38}$ FO 371 11939. D. n. 41 Sir H. Rumbold to Sir A. Chamberlain. Madrid, 4-II-1926.

${ }^{39}$ FO 371 11936. D. n. 426. Sir H. Rumbold to Sir A. Chamberlain. Madrid, 27-IX-1926. 
berlain, convencido de la necesidad de hacer lo posible para estimular el retorno de España a la Sociedad, mostró su disposición a que se reabrieran conversaciones entre España, Francia y su propio país.

Tan pronto Francia hizo ciertas concesiones a España en Tánger, en concreto el tan ansiado control de la policía, Primo de Rivera se dedicó a enfriar las relaciones con Italia. La firma del nuevo Convenio sobre Tánger tendría lugar a finales del mes de julio de 1928. Aquel mismo mes España era oficialmente invitada por el Consejo de la Sociedad a reintegrarse en la misma. La batalla diplomática se había saldado con muy modestos logros: por un lado, España regresaba a la Sociedad de Naciones aceptando la oferta que en su momento rechazó de miembro semipermanente del Consejo; y por otro, las mejoras en Tánger no podían ocultar el fracaso en su aspiración tradicional de incorporar Tánger a la zona española. Ambos reflejaban la supeditación de España al arbitraje de Gran Bretaña, el indispensable, aunque difícil entendimiento siempre, con Francia y el papel instrumental con el que mutuamente Primo de Rivera y Mussolini entendieron sus relaciones mediterráneas y europeas.

En pleno proceso negociador de la revisión del Estatuto de Tánger a lo largo de 1927 el embajador británico en Madrid, Sir Horace Rumbold, no dudaba en calificar la relación entre España e Italia como platónica ${ }^{40}$. De su entrevista con Primo de Rivera el 14 de noviembre de 1927 concluía que "he has often admitted that the geographical situation of Spain renders good relations with England a matter of expediency, and even of necessity"41.

A modo de balance desde el plano de la geocultura en el Mediterráneo y Marruecos confluirían no sólo fronteras geopolíticas imperiales, sino que convergerían fronteras y cartografías simbólicas de centros y periferias. En Marruecos desembocarían tres empresas orientalistas y tres proyectos coloniales, dos satisfechos con el statu quo y uno revisionista, que conectaría con las aspiraciones mediterráneas y coloniales de Italia. Sobre estas cartografías coloniales se proyectaría también el apaciguamiento.

La crítica al retraso español desde medios británicos también se cerniría, como ya hemos apuntado, sobre las limitaciones de España como potencia colonial y su capacidad civilizadora. Las críticas a la corrupción y la ineficacia de su ejército y su administración colonial eran ilustrativas de esa percepción periférica y dependiente.

La conexión de España con el centro del sistema internacional -Europa y la Sociedad de Naciones- seguiría realizándose de forma preferente a través

${ }^{40}$ FO 371 13439. Annual Report for Spain, 1927.

${ }^{41}$ FO 371 12715.D. n. 605. Sir Horace Rumbold to sir A. Chamberlain. Madrid, 21XI-1927. 
de la conexión mediterránea. Pero pese a estas novedades en la organización internacional, la Monarquía de Alfonso XIII perfiló la concepción y el desarrollo de su política mediterránea y europea desde claves tradicionales, más conexas con la lógica del imperialismo que con las nuevas directrices y valores del sistema internacional nucleado en torno a Ginebra.

\section{Bibliografía}

ALBI, Fernando (1931). La politica del Mediterráneo en la posguerra (1918-1928). Valencia: Tip. P. Quilés.

CAL, María Rosa Cal (1988). Los gastos reservados y la prensa con Primo de Rivera. Historia 16, 271, 72-77.

CAMPBELL, David (1998). Writing Security. United States Foreign Policy and Politics of Identity. Minnesota: University of Minnesota.

LARIO, Ángeles (2015). España desde el Reino Unido. En TORRE, Hipólito de la (coord.) España desde el exterior (1917-1923). Madrid: Editorial Ramón Areces UNED.

MORADIELLOS, Enrique (1998). Más allá de la Leyenda Negra y del Mito Romántico: el concepto de España en el hispanismo británico contemporaneísta. Ayer, 31, 183-200.

NEILA, José Luis (2011). España y el Mediterráneo en el siglo XX. De los acuerdos de Cartagena al proceso de Barcelona. Madrid: Sílex.

PEREIRA, Juan Carlos (1979). Los laboristas en el poder: actitud y reacción española (1923-1924). Revista de la Universidad Complutense, 116, 497-514.

PEREIRA, Juan Carlos (1986). Las relaciones entre España y Gran Bretaña durante el reinado de Alfonso XIII (1919-1931). Madrid: Universidad Complutense de Madrid.

PEREIRA, Juan Carlos; CERVANTES, Ángel (1992). Relaciones diplomáticas entre España y América. Madrid: Mapfre.

PEREIRA, Juan Carlos; NEILA, José Luis (2007). La España de Alfonso XIII en el sistema internacional de posguerra (1919-1931). Historia Contemporánea, 34, 117-154.

SALGADO ALBA, Jesús (1989). Evolución estratégica de la Marina española entre las dos guerras mundiales. En Les armées espagnoles et françaises. Modernisation et réforme entre les deux guerres mondiales, Madrid : Annexes au Mélanges de la Casa de Velázquez.

SUEIRO, Susana (1992). España en el Mediterráneo. Primo de Rivera y la "Cuestión marroqui", 1923-1930. Madrid: UNED.

SUEIRO, Susana (2000). La política exterior de España en los años veinte: una política mediterránea con proyección africana. En TUSELL, Javier; AVILÉS, Juan; PARDO, Rosa (eds.). La política exterior de España en el siglo XX (135-158). Madrid: Biblioteca Nueva.

TUSELL, Javier; QUEIPO DE LLANO, Genoveva (1986). El dictador y el mediador. España-Gran Bretaña 1923-1930. Madrid: CSIC. 